R. Michel • N. Mischler • B. Azambre •

G. Finqueneisel · J. Machnikowski · P. Rutkowski •

T. Zimny $\cdot$ J. V. Weber

\title{
Miscanthus $\times$ Giganteus straw and pellets as sustainable fuels and raw material for activated carbon
}

Received: 10 January 2006 / Accepted: 7 March 2006 / Published online: 10 June 2006

(C) Springer-Verlag 2006

\begin{abstract}
Miscanthus $\times$ Giganteus is an excellent candidate for energy cultivation. Here we report, for the first time, the results of the pyrolysis of Miscanthus $\times$ Giganteus straw or pellets both in tubular reactor $(3-6 \mathrm{~g})$ and in rotary kiln $(10-30 \mathrm{~g})$. At $400-600^{\circ} \mathrm{C}$ the fractions obtained from both reactors are: solid 16-25 (wt.\%); liquids 25-40; water 15-20 and gases 15-50. GC-MS analyses of pyrolysis liquids reveal the occurrence of phenolic derivatives and ethanol from lignin, furanic and linear oxygenated compounds from cellulose and hemicellulose. Finally the chars produced by the pyrolysis of $\mathrm{M} \times \mathrm{G}$ pellets in rotary kiln present good calorific values close to $29,000 \mathrm{~J} / \mathrm{g}$. Additionally, activated carbons with a BET surface area as high as $800-900 \mathrm{~m}^{2} / \mathrm{g}$ are produced from pellets. These results indicate that chars have a good potential either for energy production, e.g. briquetting, or as adsorbents precursors.
\end{abstract}

Keywords Renewable energy - Biomass - Miscanthus · Pyrolysis $\cdot$ Pellets $\cdot$ Straw $\cdot$ Chars $\cdot$ Bio oils

\section{Introduction}

In the field of renewable energy the European Commission target for 2010 can be summed up by the figure of 100 million tons oil equivalent (toe) for wood and energetic culture sources [European Parliament (2001)—Directive 2001/77/CE]. This objective is reinforced by the crisis of

R. Michel · B. Azambre · G. Finqueneisel · T. Zimny ·

J. V. Weber $(\triangle)$

Laboratoire de Chimie et Applications, Université de Metz, rue V. Demange,

57500 Saint Avold, France

e-mail: Jvweber@univ-metz.fr

N. Mischler

Université de Metz, IUT - département Chimie,

rue V. Demange,

57500 Saint Avold, France

J. Machnikowski · P. Rutkowski

Faculty of Chemistry, Wrocław University of Technology,

Gdańska 7/9,

50-344 Wrocław, Poland petroleum due to its decreasing availability and increasing price. Unfortunately, the sector of bioenergy is currently not growing at a satisfactory pace, and the objectives that have been set will probably not be reached unless new technological developments come to light. In our previous papers (Collura et al. 2005, 2006) we described the thermal behaviour and the combustion properties of Miscanthus Giganteus a potential candidate for energy cultivation (Acaroğlu and Aksoy 2005). Our conclusions were that a net energy yield in the domain 152-312 MJ/ha/year can be calculated for the cultivation of Miscanthus leading to an energy balance estimated between 7.7 and 15.4. Nevertheless, because transport costs and storage are crucial from an economical viewpoint, the ratio energy content/volume has also to be optimised. Pyrolysis of biomass products leading to liquids (bio oils) or bio chars or even gasification may be used to overcome this problem. It is well established that the pyrolysis of biomass gives solid, liquids and gases. The distribution of the different fractions is strongly connected with the experimental conditions. Schematically, in inert atmosphere the production of liquids and gases is favoured at high heating rate, high flow rate of carrier gas and mediumhigh temperatures, whereas the formation of solid chars is rather promoted at low heating rate, low flow rate and lowmedium temperatures. This is explained by the well known two parallel steps scheme of biomass thermal behaviour (Bradbury et al. 1979).

\section{Biomass}

Way $1>$ char + gases

Way $2 \longrightarrow$ volatile tars

The way 1 is preponderant at low heating rate and becomes negligible at high heating rate. To sum up, there are two extreme strategies in order to reduce the volume of biomass and to optimise the ratio energy/volume. The first one is the liquids production (Meier and Faix 1999). In this case yields can be as high as 70\% (in wt) of organic liquids (without water and on dry wood basis) and $15 \%$ gases. The crude fast pyrolysis oil is well suited for the generation of heat and electrical power. Another asset of burning 
pyrolysis oils instead of wood is the lower emission of $\mathrm{CO}$, dust, and tar. Pyrolysis liquids can be co-burned with mineral oils in an effective high-tech boiler (Meier and Faix 1999). The main drawback related to pyrolysis oil being its poor long term stability. The second possibility is chars and gases production. Again two aspects can be considered. First, bio-solid production is an effective solution for the preparation of solid fuels or active carbon. In this case liquid and gaseous fractions can be used for the energy balance of the process. Secondly, solid can be used as raw material in clean gasification process. To our knowledge, Miscanthus chars production is poorly described in the literature (de Jong et al. 2003). For this reason, considering Miscanthus as a promising renewable energy source, we have studied in this work its pyrolysis at laboratory scale by using a tubular fixed bed reactor or in a rotary kiln. The liquids obtained in both cases were characterised by GC/MS, the gases evolution was analysed by infrared spectroscopy and the chars by $\mathrm{N}_{2}$ adsorption at $77 \mathrm{~K}$. Also data reported on the pyrolysis of biomass pure components (cellulose, hemicellulose and lignin) carried out in similar conditions are given in order to provide useful insights in the thermal behaviour of Miscanthus straw and pellets.

\section{Experimental}

\section{Raw material}

Miscanthus $\times$ Giganteus was provided by the farm F.J. Koch, Kenn Saarland-Germany and was harvested in March 2004. Its biochemical composition is (wt.\% dry basis): cellulose - 45; hemicellulose-30 and lignin: 21 (Collura et al. 2005). The volatile matter and ash contents were determined by combustion in TGA by pyrolysis at $900^{\circ} \mathrm{C}$ followed by combustion. Pellets were also provided by the farm F.J. Koch, Kenn Saarland-Germany and classically produced by extrusion without any additive. They were individual cylinders of $6 \mathrm{~mm}$ wide by $10-30 \mathrm{~mm}$ in length. Some characteristics of Miscanthus are reported in Table 1.

The model constituents used in this work were: cellulose (microcrystalline Aldrich CAS No. 9004-34-6); hemicellulose (xylan Aldrich CAS No. 36,355-3) and lignin (Organosolv Aldrich CAS No. 8068-03-9).

\section{Pyrolysis in a tubular reactor}

Samples (3-6 g, 100\% <1 mm) of straw loaded in an aluminium crucible were introduced in a quartz tubular reactor $\left(2.9 \mathrm{~cm}\right.$ internal diameter) preheated at $400^{\circ} \mathrm{C}$ under a flow of $\arg$ on $(200 \mathrm{ml} / \mathrm{min})$. Organic liquids and water were re- covered in a trap at $-110^{\circ} \mathrm{C}$ and non-condensable gases were analysed on-line using Biorad FTS185 spectrometer equipped with a gas cell by infra red spectroscopy. Each pyrolysis experiment was stopped when the amount of gases detected was found to become negligible ( $\mathrm{ca} 70 \mathrm{~min}$ at $400^{\circ} \mathrm{C}$ for all samples). Solid and liquid fractions were subsequently weighted and the total amount of gases was determined by difference. The water content inside the liquids was determined separately using the Karl-Fisher method.

\section{Pyrolysis in a rotary kiln}

The pyrolysis of both straw and pellets was carried out in a rotary kiln (1300 $\mathrm{mm}$ length and $63 \mathrm{~mm}$ internal diameter) under argon flow $\left(201 \mathrm{~h}^{-1}\right)$. Between 10 and $30 \mathrm{~g}$ of samples (as received pellets or straw see Collura et al. 2006) were heated up to 500 or $600^{\circ} \mathrm{C}$ at heating rates between 2.5 and $15^{\circ} \mathrm{C} / \mathrm{min}$. Liquid products were recovered in an external collector. Gas yield was calculated by difference.

Gas chromatography/mass spectrometry analysis of the liquids

The liquids were analysed using an Agilent 6890 series GC system supplied with 5973 mass selective detector using either a Optima I capillary column $(50 \mathrm{~m}-0.2 \mathrm{~mm}$ i.d.$0.5 \mu \mathrm{m}$ film thickness OV-1) or a HP 5MS capillary column $(30 \mathrm{~m}-0.25 \mathrm{~mm}$ i.d. $-0.25 \mu \mathrm{m}$ crosslinked 5\% PHME Siloxane). using a temperature program from 40 ( 30 s hold $)$ to $60^{\circ} \mathrm{C}(30 \mathrm{~s}$ hold $)$ with an heating rate of $1^{\circ} \mathrm{C} \mathrm{min}^{-1}$ then to $185^{\circ} \mathrm{C}(10 \mathrm{~min}$ hold $)$ with an heating rate of $3^{\circ} \mathrm{C} \mathrm{min}-1$. The mass spectrometer was set at an ionizing voltage of $70 \mathrm{eV}$ in EI mode with mass range $m / z 15-400$. The identification of organic compounds was accomplished by comparing mass spectra of the resolved components with the NIST98 library.

\section{Characterization of chars}

The heating value (HHV) and volatile matter (on dry ash free basis, $\mathrm{V}^{\mathrm{daf}}$ ) of chars were determined according to Polish Standards. Steam activation process was applied as the method of porous structure development of chars obtained from pellets. The sample was heated up to $800^{\circ} \mathrm{C}$ at $5^{\circ} \mathrm{C} / \mathrm{min}$ under nitrogen and after 15 min soaking the $\mathrm{N}_{2}$ flow was switched to steam and the process was continued up to about 50 wt.\% burn-off. The porous structure of the activated carbons was characterised

Table 1 Some characteristics and elemental composition of the studied Miscanthus (in wt \%—dry basis)

\begin{tabular}{llllllllll}
\hline Ash & Volatile matter $\left(900^{\circ} \mathrm{C}\right)$ & Moisture $($ wt.\%) & $\mathrm{C}$ & $\mathrm{H}$ & $\mathrm{S}$ & $\mathrm{N}$ & $\mathrm{Cl}$ & $\mathrm{O}(\mathrm{dif})$ & $\mathrm{HHV}(\mathrm{MJ} / \mathrm{kg})$ \\
\hline 2.3 & 80 & 9.6 & 47.1 & 5.38 & 0.06 & 0.44 & 0.074 & 44.6 & 17.744 \\
\hline
\end{tabular}

${ }^{\mathrm{a}} \mathrm{HHV}$ : higher heating value $\mathrm{O}($ dif) oxygen by difference 


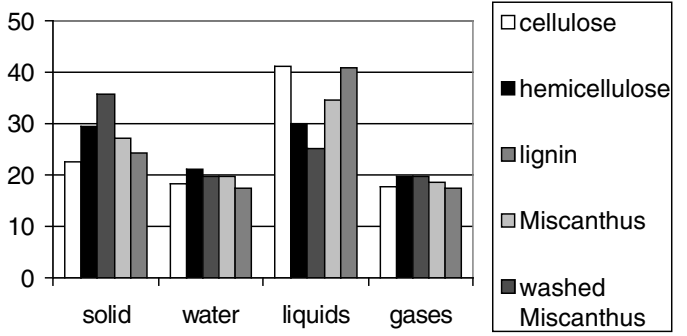

Fig. 1 Distributions of the solid, liquids, water and gaseous fractions obtained by the pyrolysis at $400^{\circ} \mathrm{C}$ in the tubular reactor (wt.\%)

by adsorption/desorption of nitrogen at $77 \mathrm{~K}$ using an automatic adsorption unit NOVA2200 (Quantachrome).

\section{Results and discussion}

\section{Mass distribution of pyrolysis fractions}

For comparative purpose, the pyrolysis of the Miscanthus was studied in parallel with the pyrolysis, under the same conditions, of some model constituents: cellulose; hemicellulose and lignin. The distributions of the solid, liquid and gaseous fractions obtained for the pyrolysis of biomass model constituents and Miscanthus samples in the tubular reactor at $400^{\circ} \mathrm{C}$ are reported in Fig. 1. First, because of its high carbon content, the lignin has the higher proportion of solid residue $\left(35 \mathrm{wt} . \%\right.$ at $\left.400^{\circ} \mathrm{C}\right)$ whereas cellulose has the lower one (21 wt.\%). Considering the tar fraction, the situation is reversed. In comparison, the distribution of gases and water fractions is considerably less affected at this temperature by the source of biomass. On the other hand, the hemicellulose always presents an intermediate behaviour between cellulose and lignin. In all cases, the main gases detected by FTIR spectroscopy during pyrolysis at $400^{\circ} \mathrm{C}$ (not shown here) were $\mathrm{CO}_{2}, \mathrm{CO}$ and $\mathrm{CH}_{4}$, the amount of methane produced in the course of lignin char formation being significantly higher due to cracking of aliphatic chains located between phenolic basic units.

In comparison with pure biomass constituents, the distribution of Miscanthus pyrolysis fractions follows an intermediate behaviour, which roughly corresponds to the distribution of its constituents. It is well known that minerals can have sensible effects on the thermal behaviour of biomass samples. For this reason the thermal behaviour of washed Miscanthus was also studied (Adam et al. 2005; MüllerHagedorn et al. 2003). In our case, we found that a simple washing in water at room temperature leads to a sensible decrease of the ash content as observed by TGA/combustion (solid residue after combustion at $900^{\circ} \mathrm{C}<0.5 \mathrm{wt} . \%$ ) and analysis by atomic absorption spectroscopy (\% removed after washing: $\mathrm{K}^{+}: 59(0.107 \mathrm{wt} . \%) ; \mathrm{Na}^{+} 75(0.014 \mathrm{wt} . \%)$; $\mathrm{Ca}^{2+} 28$ (0.213 wt.\%) and $\mathrm{Mg}^{2+} 47(0.240$ wt. $\left.\%)\right)$.

The main effects of washing were a logical decrease of the solid fraction $(-3 \mathrm{wt} . \%)$ and an increase of the tars fraction $(+6 \mathrm{wt} . \%)$. The removal of minerals can explain in part the decrease of the mass of solid residue, but more interestingly it seems that the presence of the minerals in

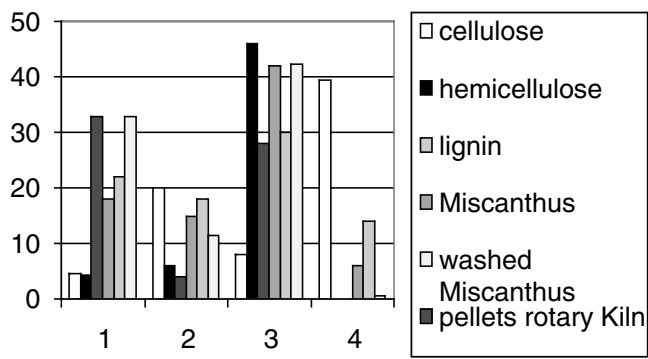

Fig. 2 Distributions of the different classes of compounds calculated by GC/MS (in \% of the total chromatogram area). (1) aromatic and phenolic compounds; (2) furanic compounds; (3) linear oxygenated compounds; (4) sugar derivatives. N.B. some different substituted pyran are found but in all cases in very low amounts

the Miscanthus has two effects during the pyrolysis. The first one is to favour the way of water and gases production and the second to decrease the amount of tar. This can be explained on the basis of the scheme of A.G.W. Bradbury et al. (1979) given in the introduction. The minerals are catalysts for the way 1 . Considering the analysis of the liquids (results given in the Fig. 2) it can be also assumed that the effect of the minerals is to favour the opening of the sugar cycles. To sum up, the production of gases and solid from the Miscanthus (way 1) seems to be connected with the opening of sugar cycles and water production, these reactions are catalysed by the minerals present.

The mass balance in the rotary kiln experiments are reported in Table 2. The first observation is classically, the lower the heating rate the higher the yield in solids and the higher the yield in liquid. The second one is: the gaseous fractions are in all cases close to $50 \mathrm{wt} . \%$. This has to be connected to the experimental conditions used in the rotary kiln where the residence times are in the range $30 \mathrm{~s}$ to $1 \mathrm{~min}$. In comparison, we estimate the residence time in the tubular reactor to be less than $5 \mathrm{~s}$. The longer the residence times the higher the cracking reactions inducing the production of gaseous compounds.

The comparison of Miscanthus straw and pellets behaviours shows that in all cases the solids amounts from straw are higher than those of pellets (between $4 \mathrm{wt} . \%$ at $600^{\circ} \mathrm{C}-5 \mathrm{~K} / \mathrm{min}$ to $10 \mathrm{wt} . \%$ at $\left.600^{\circ} \mathrm{C}-15 \mathrm{~K} / \mathrm{min}\right)$. In general, it is well established that the solid production in

Table 2 Fractions distribution for the pyrolysis of straw and pellets in the rotary kiln (wt.\%)

\begin{tabular}{llllll}
\hline $\begin{array}{l}\text { Final } \\
\text { temperature }\left({ }^{\circ} \mathrm{C}\right)\end{array}$ & Sample & $\begin{array}{l}\text { Heating rate } \\
(\mathrm{K} / \mathrm{min})\end{array}$ & Char & Liquids $^{\mathrm{a}}$ & Gas \\
\hline 500 & Pellets & 15 & 22 & 31 & 47 \\
& & 5 & 23 & 26 & 51 \\
& & 2.5 & 25 & 26 & 48 \\
& Straw & 15 & 28 & 26 & 46 \\
& & 5 & 29 & nd & nd \\
600 & Pellet & 15 & 16 & 34 & 50 \\
& & 5 & 23 & 29 & 48 \\
& Straw & 15 & 26 & 28 & 46 \\
& & 5 & 27 & 24 & 49 \\
\hline
\end{tabular}

${ }^{a}$ Including water; nd: not determined 
Table 3 Amounts of some single compounds in the liquid fractions of pyrolysis Percentage of the total area of the chromatogram

\begin{tabular}{llll}
\hline \multirow{2}{*}{ Compound } & \multicolumn{2}{l}{ Tubular reactor $\left(400^{\circ} \mathrm{C}\right)$} & \\
\cline { 2 - 3 } & $\mathrm{M} \times \mathrm{G}$ & Washed $\mathrm{M} \times \mathrm{G}$ & Rotary kiln pellet $\left(500-15^{\circ} \mathrm{C} / \mathrm{min}\right)$ \\
\hline 1-Hydroxy 2-propanone & 8.4 & 4.8 & 11 \\
1-Hydroxy 2-butanone & 2.6 & 0.6 & 3.6 \\
Furfural & 7 & 10 & 0.8 \\
2-Methoxy phenol & 2.1 & 1.4 & 5 \\
2,6 Dimethoxy phenol & 2 & 1.8 & 6.7 \\
\hline
\end{tabular}

Table 4 Characteristics of the chars and activated carbons produced from $\mathrm{M} \times \mathrm{G}$ pellets in the rotary kiln

\begin{tabular}{|c|c|c|c|c|c|c|}
\hline \multirow[b]{2}{*}{ Final temperature $\left({ }^{\circ} \mathrm{C}\right)$} & \multicolumn{2}{|l|}{ Char } & \multicolumn{4}{|c|}{ Activated carbon } \\
\hline & HHV (J/g) & $V^{\text {daf }}(\mathrm{wt} \%)$ & $\overline{S_{\mathrm{BET}}\left(\mathrm{m}^{2} / \mathrm{g}\right)}$ & $V_{\mathrm{T}}\left(\mathrm{cm}^{3} / \mathrm{g}\right)$ & $V_{\mu}\left(\mathrm{cm}^{3} / \mathrm{g}\right)$ & $V_{\mathrm{M}} / V_{\mathrm{T}}$ \\
\hline$\overline{500}$ & 29,083 & 15.25 & 820 & 0.569 & 0.328 & 0.426 \\
\hline 600 & 29,530 & 9.40 & 940 & 0.514 & 0.387 & 0.245 \\
\hline
\end{tabular}

$\mathrm{HHV}$, higher heating value; $S_{\mathrm{BET}}$, surface area; $V_{\mathrm{T}}$, total pore volume; $V_{\mu}$, micropore volume; $V_{\mathrm{M}}$, mesopore volume biomass pyrolysis proceeds via vapour/solid interactions. In this sense, for pellets these multiphase reactions are theoretically favoured. Our results, on the contrary demonstrate that the reversal behaviour is observed. At least, two hypotheses could be invoked to explain this effect. First, the thermal conditions within the biomass are very different and secondly pelletising leads to some mechanochemical transformations of the raw Miscanthus.

\section{Characterization of the liquids fractions}

Semi-quantitative GC-MS was performed on the liquid fractions obtained in the tubular reactor at $400^{\circ} \mathrm{C}$ and the fraction obtained from the pyrolysis of pellets in rotary kiln at $500^{\circ} \mathrm{C}\left(5^{\circ} \mathrm{C} / \mathrm{min}\right.$ in Fig. 2). The production of aromatic compounds (including phenols) can be attributed in all cases, quasi-exclusively to lignin, which is evident considering the phenolic structure of this natural polymer. The thermal behaviours of cellulose and hemicellulose, under our conditions, are clearly different. The degradation of cellulose produces preferentially substituted furanic compounds (mainly furfural) and sugars derivatives (mainly levoglucosane); reversely hemicellulose produces preferentially water and linear oxygenated products (acetic acid and hydroxypropan-2-one). Besides aromatic and phenolic compounds, lignin yields also large amounts of linear oxygenated products. The situation for Miscanthus is more complex. It is noticed that the observed distribution is not as simple as additive, because otherwise, the amount of linear oxygenated products (group 3 in Fig. 2) would be less than observed. Therefore, it seems that interactions between pyrolysis products take place during Miscanthus pyrolysis, leading to the formation of a more large quantity of secondary products. Furthermore, the effect of the washing is evidenced by an increase of group 4 (sugar derivatives) compounds with a decrease of linear oxygenated products. Despite the very different experimental conditions used $\left(5^{\circ} \mathrm{C} / \mathrm{min}\right.$ and $500^{\circ} \mathrm{C}$ in Fig. 2), the GC/MS analysis of liquids produced during pyrolysis of pellets in the rotary kiln gives rather comparable results, linear oxygenated liquids being the most abundant group. The important aromatic compounds group can be simply explained by the method of separation using toluene in the case of pellets.

Finally, it should be added that some single compounds are found in non negligible amounts (in \% of the total area of the chromatograms) in all analysed fractions (see in Table 3).

\section{Characterization of the biochars}

Biochars obtained by pyrolysis can have several uses in different domains. As solid fuels, for example, a high heating value is needed, as adsorbents a high specific area with a high microporous volume are targeted. The $\mathrm{M} \times \mathrm{G}$ chars produced from pellets in the rotary kiln at 500 and $600^{\circ} \mathrm{C}$ by using a heating rate of $15^{\circ} \mathrm{C} / \mathrm{min}$ were evaluated as a potential energy or adsorbent sources after steam activation (see experimental part). Some of their characteristics are reported in Table 4.

The obtained chars, with a mean HHV of $29 \mathrm{MJ} \mathrm{kg}^{-1}$ and fixed carbon content higher than $80 \mathrm{wt} . \%$ can be used as solid fuels. Moreover, pellets meet the requirements for the raw material to make category-A briquettes for domestic use according to French and Belgian standards (González et al. 2003). It should be also noted that the porous system of both activated carbons is well developed. Therefore, there is a possibility of pellets application as a precursor for activated carbon manufacturing. Furthermore, it should be noted that the final temperature of pyrolysis of the $\mathrm{M} \times \mathrm{G}$ pellets is a crucial parameter on the final porous distribution after steam activation, opening the possibility to produce activated carbon having a developed mesoporosity (final temperature $500^{\circ} \mathrm{C}$ - see Table 4) or not (final temperature $\left.600^{\circ} \mathrm{C}\right)$.

Acknowledgement This work is supported by the city of Saint Avold (France) "projet Miscanthus" and the French agency for innovation (ANVAR) "project AJI". 


\section{References}

Adam J, Blazsó M, Mészáros E, Stöcker M, Nilsen MH, Bouzga A, Hustad JE, Grønli M, Øye G (2005) Pyrolysis of biomass in the presence of Al-MCM-41 type catalysts. Fuel 84(12-13): 1494-1502

Acaroğlu M, Aksoy AS (2005) The cultivation and energy balance of Miscanthus $\times$ giganteus production in Turkey. Biomass Bioenerg 29(1):42-48

Bradbury AGW, Sakai Y, Shafizadeh F (1979) A kinetic model for pyrolysis of cellulos langnp2057e. J Appl Polym Sci 23:32713280

Caputo AC, Palumbo M, Scacchia F (2005) Economics of biomass energy utilization in combustion and gasification plants: effects of logistic variables. Biomass Bioenerg 28:35-51

Collura S, Azambre B, Weber JV (2005), Thermal behaviour of Miscanthus grasses, an alternative biological fuel. Env Chem Lett 3:95-99
Collura S, Azambre B, Finqueneisel G, Zimny T, Weber JV (2006) Biomass as a renewable source of energy. The case of Miscanthus $\times$ Giganteus $(\mathrm{M} \times \mathrm{G})$. Part II: Energy and emission tests of the combustion of straw and pellets. Env Chem Lett. in press

de Jong W, Pirone A, Wójtowicz MA (2003) Pyrolysis of Miscanthus Giganteus and wood pellets: TG-FTIR analysis and reaction kinetics. Fuel 82(9):1139-1147

González JF, Encinar JM, Canito JL, Sabio E, Chacón M (2003) Pyrolysis of cherry stones: energy uses of the different fractions and kinetic study. J Anal Appl Pyrolysis 67(1):165-190

Meier D, Faix O (1999) State of the art of applied fast pyrolysis of lignocellulosic materials-a review. Bioresource Technol 68(1):71-77

Müller-Hagedorn M, Bockhorn H, Krebs L, Müller U (2003) A comparative kinetic study on the pyrolysis of three different wood species. J Anal Appl Pyrol 68-69:231-249 